\title{
And a Hero Will Save Us; What Do Heroes from Ancient and Medieval Epics Teach Us in the 21st Century?
}

\author{
By Jonathan Needham*
}

\begin{abstract}
Heroic characters portrayed in world epics serve as universal archetypes, adhering to the theories of Campbell and Jung, throughout the centuries. Through careful analysis of these figures and their noble qualities and feats, we come to realize that they continuously shape us in the $21^{\text {st }}$ century. Examining traits like fear, courage, and sacrifice, leitmotifs found among the heroes of world epics, also seen in the characters of superhero comics of the 1980s and before, invites us to reflect upon an important idea about humanity: we, vying for material supremacy today, should recall the timeless moralistic values that heroes potentially instill in each of us. Such emblematic figures are truly an "extension" of us. In fact, our recollection and continuous acknowledgement of these magnanimous figures enable the "genuine" hero inside us all ultimately to emerge and allow each of us to die honorably on life's journey of discoveries.
\end{abstract}

\section{Introduction}

Gilgamesh, Odysseus, and Roland- these are just a few of the courageous warrior-kings and gallant knights known to practically all avid readers of world literature. Their tales, their adventures have enthralled audiences of both the eastern and western worlds from time immemorial, so it seems. At the dawn of ancient civilizations, bards narrated tales often accompanied by music about heroic figures and fantastic beings such as the ones mentioned above. In the Middle Ages, the jongleurs (minstrels, court jesters) traveled from region to region in Western Europe and recounted to members of nobility the honorable, noble acts of heroes like Roland at the time of the Frankish king Charlemagne. ${ }^{1}$ Even today we idealize traits of these virtually dauntless figures. According to the renowned American author and teacher of comparative mythologies Joseph Campbell, these celebrated heroes of myth and legend in general place others before themselves, achieve something beyond the normal range of accomplishment, and one of the most admirable and indelible qualities, they make sacrifices for their ideals. If we examine the concept of archetype and

\footnotetext{
*Senior Lecturer of Italian and French Studies and Ancient Mediterranean Civilizations, Penn State University, USA.

1. For those interested in knowing in depth about the origins of The Song of Roland and other French epics originating from the time of Charlemagne, please consult Philip E. Bennett's informative article (Philip E. Bennett, "Origins of the French Epic: The Song of Roland and Other French Epics," Approaches to Teaching the Song of Roland, ed. Leslie Morgan and William W. Kibler (New York: MLA, 2006).
} 
collective unconsciousness formed by the prominent Swiss psychologist Carl Jung, an idea that Campbell built on to encompass all world mythologies, in order to explain the commonality of dream images and situations found in all people, it immediately draws our attention to the following lines:

Heroes are constructions: They are not real. All societies have similar hero stories not because they coincidentally made them up on their own, but because heroes express a deep aspect of human existence. They can be seen as a metaphor for the human search of self-knowledge. ${ }^{2}$

Regardless of whether or not heroic figures like Odysseus or Roland actually existed, the important issue we must grasp here is that they serve as a "metaphor for the human search of self-knowledge." This means, through his acts, the hero shows us the path to our consciousness, i.e. what makes us unique as hypothesized by Jung. ${ }^{3}$

Even in the $21^{\text {st }}$ century, in a world that is noticeably changing through the continuous advent of new technology, new ways of thinking and accomplishing tasks, lost in and at times bewildered by such conundrum, we long to have symbols of hope, magnanimity, and self-sacrifice that we may idealize in our "human search of self-knowledge." Even though the heroes of modern pop culture, i.e. those on television, in cinema and in comic books, do display these traits, the traditional, classic heroes of ancient and medieval times have their origins in the epics of primarily the oral tradition. In fact, it is the source or sources from which we depart on a quest, similar to Gilgamesh, Odysseus, and even Dante in The Divine Comedy, to understand ourselves in the $21^{\text {st }}$ century. Nevertheless, as we examine some of the traits of heroes already named above we must also remember that our own definition of what constitutes a hero has actually been redefined due to our changing values in the $21^{\text {st }}$ century. We will of course examine this issue later in this article.

2. Bryan M. Davis, The Archetypal Hero in Literature, Religion, Movies, and Popular Culture (Stephen F. Austin University, 11 Oct. 1997), last modified December 21, 2013, http://tatsbox.com/hero/.

3. Jung defined his concept of the archetype as the following: "... we discover them to be the formulated resultants of countless experiences of our ancestors. They are, as it were, the psychic residua of numberless experiences of the same type." For a more in-depth look at Jung's ideas about the archetype, see p. 500 in the introduction to chapter IV, "Critical Perspective: Archetypal" in Walter Gordon's anthology (Walter K. Gordon, Literature in Critical Perspectives (New York: Meredith Corporation, 1968)). Archetypes can be viewed the precursor to conscious thought, existing in the unconscious mind as expressions of psychic happenings, but without a basis in the physical world. Humans did not "invent" archetypes, but they do express archetypes in the conscious world of art, literature, and religion. For more on this, please refer to Bryan Davis' online article (Davis, The Archetypal Hero in Literature). 
Let us embark on this unique journey. While reading Stephen Mitchell's English version of Gilgamesh, ${ }^{4}$ inspired by the scholar-priest Sin -leqi- Unninni's $13^{\text {th }}$ century B.C.E. Standard version of the epic, ${ }^{5}$ and Robert Fagles' translations of Homer's The Iliad and The Odyssey, ${ }^{6}$ we discover in these figures primordial characteristics, again connected to Carl Jung's idea of the archetype and collective unconscious. Certain of us aspire towards discovering or re-discovering in ourselves the natural, primordial traits that characters such as Gilgamesh, Odysseus and the medieval knight Roland possess. Through their exploits and deeds, not only are they figures with whom we can identify, but also they have served as role models for us even now although they too are not perfect. However, certain people in the $21^{\text {st }}$ century may be aware of the timeless, virtuous qualities that emanate from such heroes, but unfortunately, many have lost sight of them as they are being consumed, now more than ever, by materialism. For example, our egos seem to have taken over our sense of community and sensitivity to human emotions because they are often absorbed in texting and computer technology. In fact, these modern ways of communication are making us somewhat unsociable and impervious. At any rate, many of the characteristics we see in epic heroes could prove invaluable or paradigmatic to building our own character as certain of us are often questioning the rapid changes in our world and at the same time trying to understand mankind's place in it, due to globalization and industrialization in the new millennium. ${ }^{7}$

One of the traits we remark in ancient heroes like Gilgamesh and Odysseus from whose stories we can learn much today is their ability to accept fear and face it. As courageous and mighty they may appear to us, these heroes do feel fear. They fear obstacles, they fear monsters, and they fear what lies beyond, both

4. Gilgamesh, trans. Stephen Mitchell (New York: Free Press, 2006).

5. Please consult Stephen Bertman's text to find out more about the origins of the Epic of Gilgamesh (Stephen Bertman, Handbook to Life in Ancient Mesopotamia (New York: Oxford University Press, 2005)).

6. Homer, The Iliad, trans. Robert Fagles (New York: Penguin, 1991); Homer, The Odyssey, trans. Robert Fagles (New York: Penguin, 1997).

7. Joseph Campbell, The Hero with a Thousand Faces (Novaro: New World Library, 2008), 334. In his book, Joseph Campbell provides a rather intriguing explanation of what has happened to societies that related to their people heroic stories of myth and legend. He affirms: "the social unit is not a carrier of religious content, but an economic-political organization. Its ideals are not those of the hieratic pantomime, making visible on earth the forms of heaven, but of the secular state, in hard and unremitting competition for material supremacy and resources. Isolated societies, dream-bounded within a mythologically charged horizon, no longer exist as areas to be exploited. And within the progressive societies themselves, every last vestige of the ancient human heritage of ritual, morality, and art is in full decay." For more on this subject concerning the hero today, please see Campbell's book (333-337) mentioned above. 
physically and spiritually. Odysseus, the warrior-king of Ithaca who has longed to reach his homeland after several years of absence from his loved ones due to fighting in the Trojan War, exhibits moments of consternation in his ventures homeward bound. Yet, in Homer's The Odyssey, Odysseus' second in command and kin Eurylochus, about to commit a desecrating act along with the rest of the crew by devouring the god Helios' sacred cattle, reveals the following to Odysseus: "You're a hard man, Odysseus. Your fighting spirit's stronger than ours, your stamina never fails. You must be made of iron from head to foot."8 No matter how iron-willed Odysseus' fighting spirit may seem, we sense his fear following the deaths of his crewmembers by the angry god Zeus as punishment for eating the sacred cattle. Alone he is holding onto the trunk of a fig tree for dear life in a storm of winds and in the presence of the dreadful whirlpool Charybdis. Before this incident, prior to consulting the Theban seer Tiresias in the Underworld on how to reach Ithaca safely, the King displays absolute dismay as soon as he sees swarms of ghosts of the dead and hears their cries. He even says himself "-thousands swarming around the trench from every side- unearthly cries- blanching terror gripped me!"9

Even Gilgamesh, the reckless king of the great-walled city of Uruk, who is two-thirds divine and one third mortal, affirms to us his sense of fear on one of his ventures. We witness it in Book IV when he and his twin Enkidu reach the edge of the Cedar Forest and hear the monstrous roar of the beast they seek to kill, Humbaba: "They had reached the edge of the Cedar Forest. They could hear Humbaba's terrifying roar. Gilgamesh stopped. He was trembling. Tears flowed down his cheeks."10 Yet at that moment, he also calls on the god Shamash to protect him on this perilous quest and eventually, Gilgamesh is the one who attempts to instill courage in his brother Enkidu, terrified by his perceptions of the Humbaba's monstrous appearance, rather than the other way around.

Are we today not so different from these two figures when we have our own obstacles that we fear we may not surmount? In times of uncertainty, certain among us place our faith in our god, be it Judeo-Christian, Muslim or of some other religious denomination, in order to find the way to face our fears and aid others in finding courage inside themselves. Yet another important point to consider here is that as soon as Enkidu lays eyes on the Humbaba itself, he realizes that his perceptions are worse than reality and he suddenly becomes fearless. We learn from this moment in the epic that fear should not let the mind overestimate. However, when Gilgamesh first hears the monster's dreadful footsteps and quickly loses his confidence upon gazing at the creature's face, we also learn that fear should never be ignored. Many young people today do not truly seem to comprehend this idea since they appear to have become numb to it.

\footnotetext{
8. Homer, The Odyssey, 12.302-304.

9. Homer, The Odyssey, 11.46-8.

10. Gilgamesh, 116.
} 
Enveloped in a world of gratuitous violence, once young avid players of truly graphic video games have slaughtered their nemeses, believing that they are invulnerable, they are always ready for the next opponent or battle. Just as Gilgamesh has to learn through experience, especially when he loses his beloved brother to death and realizes that he too will one day perish, young adults today need to experience fear and consciously face or overcome it but in mentally sound ways.

In The Power of Myth Joseph Campbell explains fear as one of the first sensations an unborn and born child feels, and also a legendary or mythic hero, no matter how extraordinary he or she may appear to us, experience it as "someone who has given his or her life to something bigger than oneself."11 As implied by Campbell's lines, fear resides with sacrifice, through taking risks in one's own life, but that is a heroic characteristic which we will address later on in this analysis. Again, it does not matter how human or divine epic heroes are; they cannot remain indifferent to fear. Even for us in the new millennium, fear is a survival reflex, and we discern from the examples already given that heroes cannot gain courage, the antithesis of fear, that is the willingness to face terrors head-on, without dismay.

In the medieval Christian epic, The Divine Comedy, a work not of the oral tradition yet greatly influenced by heroic epics originating from it, before journeying through the circles of Hell with his venerated master Virgil, Dante bears witness to the disturbing words written above the gates of Hell "... Abandon every hope, ye that enter."12 He cannot help but feel uneasiness, a sense of reluctance to enter. Such discomfort culminates into terror and dismay when in canto IX of Inferno, he faces the fallen angels who block his path into Satan's stronghold and then three bloody and frightening Furies with snakes on their heads. In any case, Dante, although not virtually omnipotent like Odysseus and Gilgamesh, does display endurance in his spiritual quest similar to his ancient predecessors, but this is greatly due to the courage Virgil instills in him. Nowhere is this more evident than in canto III of Inferno when Virgil speaks to Dante as if a father were addressing his son:

And he said to me, like one experienced: "Here must all distrust be left behind, here must all cowardice be ended; we are come to the place where I have told thee thou shouldst see the woeful people who have lost the good of the intellect."13

11. Joseph Campbell, The Power of Myth, ed. Betty Sue Flowers (New York: Doubleday, 1988), 123.

12. Alighieri Dante, The Divine Comedy: Inferno, trans. John D. Sinclair (New York: Oxford University Press, 1939), 47.

13. Please see the translator John Sinclair's explanations (54-55) regarding Virgil's warning against cowardice, which may prove an eye-opening experience for Dante's readers, not just for Dante the character. 
Although we ourselves will never have to encounter in this world the grotesque creatures Odysseus, Gilgamesh and Dante face on their quests, the stories of their fear and courage teach us to accept fear and not be blind to it. The world in which we live today is not at all one of myth or legend, and we can be mortally wounded by our own monsters, that is ourselves and the dangerous weapons with which certain of us come into contact whether personally or through violent video games.

Let us examine another important trait seen in heroic figures of the past: responsibility. This quality is not innate like fear that builds an individual's courage. One usually must learn about responsibility through experience, and more often than not, in the case of Gilgamesh, Odysseus' son Telemachus, and the valiant knight Roland, through a physical or spiritual quest or both. Before we carefully weigh this characteristic, let us first take a step back to Joseph Campbell's simple definition of a hero. If he asserts that a hero is someone who has given his or her life to something bigger than oneself, then we can infer from such an explanation that responsibility is another trait which should characterize heroes of the past; they have assumed it at a young age or later on in their lives through a physical and spiritual quest. Campbell calls this the initiatory phase of a hero's journey. Through subjection to a series of tests or trials, the hero has accepted the need to grow and mature. ${ }^{14}$ Even psychoanalyst Robert Moore and mythologist Douglas Gillette contend in their insightful and lucid book, King, Warrior, Magician, Lover: Redefining the Archetypes of the Mature Masculine that "In order for man psychology to come into being for any particular, there needs to be a death. Death-symbolic, psychological, or spiritual- is always a vital part of any initiatory ritual. In psychological terms, the boy Ego must 'die'."15

In Gilgamesh's case, at first the wanton and haughty king of Uruk, he later bears witness to the un-timely death of his brother Enkidu and then eventually makes his way to the Underworld, desperately searching for the secret to immortality. In spite of his failed attempt to discover it, he undergoes a spiritual transformation at the end of the epic, appearing to relinquish his old character and accept responsibility as a "mortal" king to a city and people now regarded precious to him. Although this realization has occurred in a later time in his life, it is undoubtedly the final stage of his initiation, psychologically- speaking, from boyhood into manhood.

We definitely witness in Homer's The Odyssey a young man being transformed into an individual who exhibits heroic qualities like his father

14. See chapter II entitled "Initiation" in Joseph Campbell's text The Hero with a Thousand Faces. There he provides (81-90) examples from myth and dreams concerning the trials that heroes, both male and female, have faced.

15. Robert Moore, and Gillette Douglas, King, Warrior, Magician, Lover: Redefining the Archetypes of the Mature Masculine (San Francisco: Harper San Francisco, 1991), 6. 
Odysseus: Telemachus. At first the young prince of Ithaca appears feeble and stricken with grief by the fact that his father is feared dead while suitors from around Greece lay waste to Odysseus' palace and at the same time are trying to win over his mother Penelope. Telemachus does not seem to show any signs of pride for or assume responsibility of protecting his father's kingdom, but he does see in his mind visions of Odysseus driving out these madmen from his father's domain. But they are only daydreams. When Joseph Campbell outlines the characteristics of a hero, he maintains that a hero usually cannot begin a journey to become a man if his father figure is still present. In fact, Campbell uses Telemachus' adventure as a prime example of "the father quest" in his book The Power of Myth. He says: "In one kind of adventure, the hero sets out responsibly and intentionally to perform the deed. For instance, Odysseus' son Telemachus was told by Athena, "Go find your father." That father quest is a major hero adventure for young people. That is the adventure of finding what your career is, what your nature is, what your source is." 16

As we have already stated, the trait "responsibility" is one acquired through experience; it is not innate. Though Odysseus' long years of absence from Ithaca prove quite distressing for his wife and son, the eventual news obtained by Telemachus regarding his father's whereabouts on the island of the goddessnymph Calypso gives him a sense of hope and eventually gives him the strength to assume responsibility as one who must safeguard all his fine treasures (actually his father's) from the reckless, brazen suitors at his father's palace. Once he has witnessed the return of his father, Telemachus aids him in killing their enemies, thereby restoring to the kingdom their timē, one's value and worth, respect and honor, which is at the heart of ancient Greek society. ${ }^{17}$

Of course, timē is a concept characteristic of a society now obsolete, but if we contemplate the lessons learned from both hero quests cited above, we discover that in order to be responsible, we must first respect ourselves before our need to respect and protect others. There are those of us who, like young Telemachus, intentionally take a physical and spiritual journey and through the trials and tribulations of life's experiences, undergo a spiritual transformation, and thus become dependable people. On the other hand, others, like Gilgamesh, do not

16. Campbell, The Power of Myth, 129.

17. Sarah B. Pomeroy et al., Ancient Greece: A Political, Social, and Cultural History (New York: Oxford University Press, 2012), 79. They explain that "being good at slaughtering and pillaging brings honor and glory, as well as wealth, and so warriors compete with one another in the art of killing. The purpose of this excessive striving is to enhance and preserve one's timē, one's value and worth, respect and honor. The spirit of competition permeates every facet of Greek life and is not bounded by class or gender. The highest good is to win and be called the best (aristos), whether in spear throwing, running, or chariot racing; in speaking or in displays of cunning; in weaving or crafting pots. This type of extra-competitive society is called agonistic, from the Greek word agon (contest, struggle). The instinct to compete and win permeates the society." 
consciously make that quest until much later in life and many may never take the journey at all because they are too set in their ways, acting recklessly and irresponsibly as Gilgamesh does in the first stages of kingship in Uruk before the creation of his brother Enkidu by the gods. Those types of individuals, particularly today's generation of young people, are unwilling or they do not know how to assume responsibility; they are so consumed by material things that many of them do not understand what it actually means to do so. Of course, it does not help if they live in broken homes where there is no father or mother to teach them moral values or if the parents themselves are indifferent to teaching them to their children. Are we to stand by and do nothing when as parents we have a moral obligation to teach the rights and wrongs of life to our children so that one day they do not suffer living in a dystopia filled with violence and anarchy?

In any case, in the first part of this millennium the film industry has so far produced some "thought-provoking" superhero movies that appear to impart to today's generation lessons about facing fear, accepting responsibility and making sacrifices. This has proved to be a step in the right direction since numbers of young people, caught up in the technological wonders of the $21^{\text {st }}$ century, i.e. texting, skyping, and corresponding with their friends by cellphone or through websites, either lack proper reading skills or have become less interested in reading classics, including heroic epics. As a solution to this problem, if they are reluctant to read long novels or epics, maybe we could encourage teenagers and young adults, several of them visual learners, to read and appreciate the examples learned from "old" yet entertaining superhero comic books, not current ones because they have become increasingly more graphically violent and teach less about morals. The heroes' stories and their traits in the old comic books actually resemble those of the epic heroes of the past. In any case, some readers of classic heroic epics may view characters' deaths in them quite graphic.

Another heroic figure who merits our attention with respect to our discussion about responsible heroes is the knight Roland in the medieval French epic, The Song of Roland. ${ }^{18}$ In Frederick Goldin's noteworthy translation of this medieval epic that shares with Homer and other epic predecessors a heroic vision of war and warriors, we are drawn to the conflict which arises between Roland and his companion and protector Oliver at Rencesvals. What is the conflict that causes some of us to question Roland's behavior? For those not familiar with this epic, we shall summarize briefly the events that lead up to it.

In the time of the Frankish king Charlemagne, at a moment when he and his army of men seek to spread Christianity outside the realms of Christendom, after seven long years in Spain, Charlemagne's men of significant rank in France stand before their king in council. They must decide whether the king in Saragossa Marsilion's most recent offer of peace is genuine or not. Roland, Charlemagne's

18. The Song of Roland, trans. Frederick Goldin (New York: Norton, 1978). 
beloved nephew, advises against the council sending emissaries to King Marsilion to accept his agreement to convert to Christianity in Charlemagne's court in Aix. Charlemagne's nephew does not trust him as two of the Frankish king's men were killed by the king of Spain. Yet no one appears to listen to Roland. His stepfather Ganelon recommends sending an ambassador to accept King Marsilion's offer. His stepson actually nominates him and Roland's followers approve. Later, Roland furiously accepts his stepfather's, who has just returned from Saragossa, nomination of him to lead the rear-guard through the mountain passes in the Pyrenees. Certain that Marsilion will honor his agreement, further ahead Charlemagne and his army of men return to France. Yet, this tactic is all a ruse devised by Ganelon enraged by the fact that his stepson previously nominated him to risk his life and accept King Marsilion's offer of peace. Ganelon only envisions one thing from this devious ploy to which the king of the Saracens consents: Roland's demise and that of his stepson's followers.

When the Saracens' ambush finally occurs in the defiles of the Pyrenees, Roland and members of his rear-guard are surprised and overwhelmed by Marsilion's massive army. Oliver asks his brave companion to sound the olifant (horn) to receive help from Charlemagne and his army, but Roland refuses. A conflict ensues between him and Oliver. However, after the slaughter of several of his men, Roland does sound the olifant.

To some this might seem an irresponsible act. In fact, one school of thought attributes this type of behavior to an old French term, the desmesure; "bellicose and confident of victory, he is responsible for the defeat of the rearguard but ultimately repents and thereby merits his apotheosis."19 Yet, if we consider the words expressed by translator and scholar Frederick Goldin as well as the theory raised by another group of scholars who has sought to debunk the desmesure hypothesis, we come to realize that Roland, as foolhardy as he may seem to some, actually exhibits the qualities of a responsible hero. ${ }^{20}$ How can we say this? This valiant knight remains faithful to the feudal values tying him to Charlemagne. In his introduction to the medieval epic, Goldin justifies Roland's behavior by saying:

Only from one point of view-Roland's own-is his choice completely free. From the perspective of the poem's audience, he had to do what he did, for the battle of Rencesvals was now locked into the great design of history-the glorious history of France. From that perspective, the action he takes is necessary, pre-established, and Roland's greatness lies in his willingness to

19. Catherine Jones, "Roland versus Oliver," Approaches to Teaching the Song of Roland, ed. Leslie Morgan and William W. Kibler (New York: MLA, 2006), 201.

20. Ibid., 201-206. Catherine Jones provides a detailed explanation on the opposing schools of thought concerning Roland's decision not to sound the horn right away in the first battle against the Saracens. 
carry it out. We are moved by his warrior's rapture as he speaks of the duties of the vassal, not because we share his notion of loyalty, but because we see his notion of loyalty leading him to fulfill the role into which, from the audience's point of view, history has already cast him..$^{21}$

If we reflect upon the idea previously expressed by Moore and Gillette concerning the archetypes of the mature masculine, some of us might be tempted to say, with regards to Roland's behavior, that he is caught between boyhood and manhood, but we cannot judge him this way. The fact that in the epic he re-iterates his speech on the duties of a good vassal only serves to reinforce this knight's, this "man's" absolute faithfulness to the laws of a feudal society and to his God. ${ }^{22}$ Obviously we live in very different times than this medieval knight, but apart from the brave soldiers who have given their lives fighting for their ideals in places like the Near East and Central Asia, how many among us in this millennium would display the same type of valor and loyalty that Roland demonstrates in the face of his numerous adversaries before his death? He is ready and willing to defend his dulce France ("Sweet France"), ready and willing to die a chivalrous warrior even among the pagan army, and it is his tenacity, similar to that displayed by the Spartan king Leonidas and his army in the Battle of Thermopylae on mainland Greece in 480 B.C.E., which amazes us, inspires us. Roland even declares that a vassal's duty is to stand firm and endure some hardships for his lord, which includes sustaining great wounds to his body, and not live or die a coward. We are to admire him for his heroic acts, and even today he is regarded an exemplary

\section{The Song of Roland, 20.}

22. Colin Jones, The Cambridge Illustrated History of France (New York: Cambridge University Press, 1994), 78-79. According to Colin Jones "The bonds of personal loyalty and dependence were increasingly grounded in honorary titles linked to property. The creation of these "investitures" acquired classic form in the act of homage. The vassal would kneel before his lord, place his hands in his and swear an oath of fidelity on holy relics or on the Bible, thus becoming his "man". Besides property, the lord provided protection over his vassal, who in return owed his lord consilium ("counsel") and auxilium ("aid"). As "counsel" the vassal undertook to attend the court of his lord, offer him advice and bring to him disputes for arbitration and settlement. As "aid" the vassal had to agree to follow the lord to war, possibly with a retinue of armed followers, and to provide occasional financial assistance, including payment of the lord's ransom if he were captured, gifts on the wedding of his eldest daughter and so on. The military dimension of the relationship was highly important: the grant of property was viewed as a means of enlisting the armed support of the vassal on horseback, plus possibly a retinue of knightly retainers- from Carolingian times, cavalry had become a key battlefield arm." For more on the duties of a vassal to his lord, please see Colin Jones's book (74-81). 
figure similar to the ancient warriors Hector and Achilles in Homer's The Iliad, also subjects of interest in successive literary works. ${ }^{23}$

Keeping in mind all that we have revealed so far about the traits of these ancient and medieval figures, let's now proceed to look at the final and most admirable trait of epic heroes: sacrifice. When we weigh this characteristic and what it means to make sacrifices, we refer again to Joseph Campbell's brief yet meaningful definition of a hero. If someone has given his or her life to something bigger than oneself, then that individual has undoubtedly made or makes sacrifices. We notice this trait in the death of Gilgamesh's twin brother and friend, Enkidu, Roland's undying commitment to his lord and and to "Sweet France," Odysseus's decision to leave Ithaca and his family to fight in the Trojan War, and even in his last voyage in search of the absolute, a quest invented by Dante and narrated by Ulysses (Odysseus) himself in canto XXVI of Inferno.

Before examining these examples, let us reconsider how our interpretation of a hero has changed in this millennium, particularly in regards to making sacrifices. As suggested by Campbell, ${ }^{24}$ our criteria for judging things have been obfuscated by our changing values due to the materialistic world in which we live. This includes our judgment of heroes. Erich Fromm, social philosopher and noted author, states that "from the Renaissance up until our day men have been filled with a burning ambition for fame ..." 25 This desire, especially in the sports sector, has increased even more so today since countless earnings are at stake. While striving for fame can involve sacrifice, in today's world, undertaking such a task has not always been executed through natural and honest means. For example, we esteem soldiers of war, men and women of space exploration, political figures like Martin Luther King, Jr. and Nelson Mandela, firemen and police men who gave their lives during the incidents of 9/11, and those who continue to risk their lives in the line of duty, as well as scientists who have made even in this millennium major discoveries through all their tireless research. (Nota bene: Due to the wide availability of social media websites, someone could be labeled a hero one day and then a villain the next.) Yet, there are those of us who regard also as heroic figures certain athletes who have implemented chemical enhancements to improve greatly their athletic performance. Should we sincerely revere such sports figures as heroes when others have labored "hard" to achieve their athletic fame by honest means?

Pindar, the celebrated Greek lyric poet of the first part of fifth century B.C.E., composed odes, praising athletic participants in the Panhellenic games in Greece

23. Please see Goldin's introduction (The Song of Roland, 19-20) because he provides a contrast between Roland's ability to advise the council and that of prince Hector as seen in Chaucer's Troilus and Criseyde.

24. Campbell, The Hero with a Thousand Faces.

25. Erich Fromm, Escape from Freedom (New York: Holt, Rinehart and Winston, 1976), 13. 
who achieved their victories in chariot racing, wrestling, and foot racing through natural and strenuous training. ${ }^{26}$ They did not have the technology to employ clandestinely performance-enhancing drugs. If they had had that option, a number of these victors probably would not have had cults established in their honor, given that Greek people's values were quite different back then. ${ }^{27}$

Considering the examples that we have provided here regarding our impression of the hero today seems to suggest that in the $21^{\text {st }}$ century, we have very loosely redefined what a hero is. This certainly does not always coincide with the qualities of heroes of myth and legend that Joseph Campbell outlines in The Hero with a Thousand Faces. As we have already stated, similar to us, characters like Enkidu, Odysseus and Roland are far from perfect, yet the sacrifices that each hero makes to benefit others embody the heroic figure Campbell defines in his book rather than our own, again a "loose" definition in a new age, toiling "in hard and unremitting competition for material supremacy and resources." 28

At the beginning of Gilgamesh, though the king of Uruk revels in his world of wealth and shows little regard for his own people, he suffers greatly and learns much from Enkidu's death and his own quest for immortality. However, his twin brother is the one who appears to us the actual hero in this part of the Epic. For Gilgamesh's vanities, Enkidu, although he too is bold in slaying Humbaba and the sacred Bull of Heaven, faces the ultimate sacrifice as the offended gods in council decide which brother must die. Although, at the beginning stage of his frightening dreams foreshadowing his death, he does not accept this sacrifice (as we already mentioned, fear resides with sacrifice as does courage) and even curses the priestess Shamhat who "civilized" him, in the end he resigns himself calmly to his fate without voicing other imprecations. He realizes, through the help of the god Shamash, ${ }^{29}$ that the priestess is precisely the one who gave him Gilgamesh, his intimate friend. In Book VIII we can truly sense Gilgamesh's closeness towards and esteem for his brother, which was equally reciprocated by Enkidu, in the following lines:

Hear me, elders, hear me, young men, my beloved friend is dead, he is dead, my beloved brother is dead. I will mourn as long as I breathe, I will sob for

26. Pindar, Odes for Victorious Athletes, trans. Anne Pippin Burnett (Baltimore: The Johns Hopkins University Press, 2010).

27. With respect to athletic competitions, please refer to Pomeroy et al. (Ancient Greece: A Political, Social, and Cultural History), for the explanation on the standard time.

28. Campbell, The Hero with a Thousand Faces, 334. In this book, Campbell provides an eye-opening explanation of the hero today.

29. Shamhat was the priestess of Ishtar from Uruk, whose job was to civilize Enkidu. Shamash, was the sun god, god of justice and patron of travelers and dream interpreters, and Gilgamesh's special protector. For more on this Babylonian god's and the priestess' roles in Gilgamesh, refer to Stephen Mitchell's introduction to the Epic (Gilgamesh, 13-64). 
him like a woman who has lost her only child. O Enkidu, you were the axe at my side in which my arm trusted, the knife in my sheath, the shield I carried, my glorious robe, the wide belt around my loins, and now a harsh fate has torn you from me, forever. ${ }^{30}$

Enkidu of course has surrendered himself to his fate for the love of his brother whereas Roland sacrifices himself not only for the love of his lord Charlemagne but also for the love of his country. As we have already stated, similar to the Spartan king Leonidas who battled against the Persians at Thermopylae, the French knight Roland never surrenders even after blowing feebly the horn a second time for help from Charlemagne and his army. He knows that death is near, but he keeps on slaying pagans up until the moment when the remaining ones flee realizing that they cannot kill such a formidable opponent like Roland. Even though ironically the great wound to his temple caused by blowing the olifant results in his death, Roland's courageous sacrifice at the Battle of Rencesvals undoubtedly ennobles his character. It reaffirms to us what many of us probably already know: a true hero risks his life although he or she might die because of it, like soldiers who have fought bravely and sacrificed themselves in war for the good of their homeland. We can clearly see Roland's undying commitment to his dulce France when he stretches out beneath a pine, with his face turned toward the land of Spain. He wants Charlemagne and his army of men to see that, in spite of the fact that his soul is about to leave this earthly terrain, his "fighting spirit" could never be conquered. He would have continued battling the pagans all in the name of sacrifice, that is martyrdom to his lord Charlemagne, his glorious country, and of course his God. In laisse 207 as soon as the Frankish king has located Roland's lifeless body, after fainting from grief, he gains back his strength and then mournfully expresses his reverence towards his great nephew for Roland's complete devotion to the Emperor and Christendom in the following lines:

Roland, dear friend, God set your soul in the flowers of Paradise, among his Glorious! Lord, the black hour of your coming to Spain! No day shall pass that I feel no pain for you. My strength will fail, and my joy in my strength, I'll have no man to uphold my honor; under heaven I cannot find one friend; there's all my kin, but where is the like of you! ${ }^{31}$

According to Joseph Campbell, a hero's deeds must be marked by a nobility of purpose, and he must be willing to risk his life for his ideals. The valor displayed by Roland and his sacrifice definitely characterize the hero which Campbell describes.

30. Gilgamesh, 152-153.

31. The Song of Roland, 207.2898-2905. 
Now let us examine this last trait seen in the voyages of Odysseus off to fight in the Trojan War for the glory of his homeland and during his quest for all that is knowable in Dante's Inferno. Apart from the offerings of animals, that Odysseus and crewmen make to the Olympian gods to appease them, his own sacrifice is leaving Ithaca and his beloved family to fight in the Trojan War. This long-lasting battle between the Greeks and the Trojans of course causes the deaths of several brave warriors whose physical suffering ends as soon as they perish in combat. However, for the formidable and iron-willed warrior-king Odysseus, both his physical and emotional anguish seem unending, which we can clearly see in The Odyssey. In spite of this, one line in particular of Homer's The Iliad appears to epitomize the adventurous side of his character. When some of the best fighters such as Menelaus and Nestor's son volunteer to raid the Trojan units camped for the night, Odysseus volunteers to go too as "Odysseus' blood was always up for exploit."32

Those very exploits that the warrior-king of Ithaca seeks to fulfill, including helping his fellow men to restore Greece's honor and glory after the abduction of Menelaus' wife Helen of Sparta by the Trojan prince Paris, cost him "precious" moments away from his homeland and family. The absence from his son and the affection he feels towards him become apparent when in The Iliad he utters the following lines after King Agamemnon has taunted him about his restraint in fighting:

How can you say that I hang back from fighting when Argive units spur the slashing god of war against these Trojan horsemen? Just you watch, if you'll take the time and care to taste some action, watch Telemachus' loving father lock and fight with enemy champions, stallion-breaking Trojans. ${ }^{33}$

Even though Odysseus is a man of exploits, he mentions his son's name while expressing his sincerity in fighting for Greece. This proud father's absence away from his loved ones develops into a yearning after ten long years of combat in Troy and in The Odyssey it takes around another ten years for him to return home. Yet, in spite of Odysseus' pining for his homeland, Joseph Campbell in his book The Power of Myth asserts the following:

Men sometimes confess they love war because it puts them in touch with the experience of being alive. In going to the office every day, you don't get that experience, but suddenly, in war, you are ripped back into being alive. Life is pain; life is suffering; and life is horror- but, by God, you are alive. ${ }^{34}$

32. Homer, The Iliad, 10.273.

33. Homer, The Iliad, 4.408-413.

34. Campbell, The Power of Myth, 114. 
In this millennium, several of us find ourselves always working in the office or outside it, tapping our fingers continuously and at times aimlessly on our devices of technology. Again, aside from the soldiers who serve in the military, would we have the strength and openness to make a huge sacrifice like Odysseus, spending numerous years away from our loved ones or our homeland? Some of us have no choice such as the Italian poet Dante because, due to political reasons, he was forcibly exiled from his beloved city, Florence in 1302 until his death in Ravenna in 1321.

In canto XXVI of Inferno, Dante created an innovative narrative about the last voyage of Ulysses (Roman equivalent of Odysseus) who, enveloped in a tongue of fire, relates his story to Dante the character as the poet descends through Hell with his master Virgil. Cunning and inquisitive Ulysses' last and final quest in search of the absolute is his final moment of absence from Ithaca and his family and his final moment alive. Although to some this journey may seem a lofty act, this last voyage, a forbidden one, results in the shipwreck and drowning of Ulysses and his crew. ${ }^{35}$ This type of behavior certainly supports the lines found in Robert Fagles' translation of The Iliad stating:"Odysseus' blood was always up for exploit." As already mentioned, attempting to find the absolute, the supreme, in the case of Ulysses and his men, Purgatory, the mountain of Earthly Paradise, which was "never intended" for them to reach, seems to add an aura of nobility to Ulysses' character. Yet, at the same time, this epic hero's tragic end, i.e. his self-sacrifice in search of all that is knowable, conveys an important lesson to us today amidst all our new technology: Since man has developed an "insatiable" appetite, often seeming like an obsessive disorder, for new modes of communication, new ways of letting gadgets think for him, might he too make a self-sacrifice and "drown," trying to find a place that maybe was not actually meant for him to discover? In that case, whom would we praise then as heroes, our devices?

Certain of us might be tempted to say that the hero and his character must fit the time period in order for him or her to appear valid. It may be true

35. Lino Pertile, "Introduction to Inferno," The Cambridge Companion to Dante, ed. Rachel Jacoff (New York: Cambridge University Press, 2007), 67-106. For an engaging interpretation of Ulysses' failed voyage to search for knowledge, please consult the text The Cambridge Companion to Dante. In the essay entitled "Introduction to Inferno" by professor and scholar of Italian studies, Lino Pertile, he writes (82-83): "Ulysses is truly a tragic character. We see him sailing for five months towards the desert island of ultimate knowledge; we know that he is going in the right direction, and yet we also know that he will be stopped before he reaches the new land -the Earthly Paradise cannot be taken by storm, what Adam lost cannot be recovered by willpower alone. Ulysses is a character in whom subjective innocence and objective guilt appear to be in conflict with each other- if not quite the "pyramid planted in the mud of Malebolge" that Francesco De Sanctis wrote about in 1870, nonetheless a noble figure whose longing to reach beyond our restricted horizon still strikes us as quintessentially human." 
that the hero archetype is forever adapting with us in order to, in the words of the scholar Robert McElvaine, "reconcile existing social tensions, affirm community values and give people symbols to help shape their identities."36 His very remarks regarding the hero archetype seem to echo those of Swiss psychologist Carl Jung. However, if, according to Jung, heroes serve as a metaphor for the human search of self-knowledge, we as a society enveloped in a world vying for material supremacy must be conscious and willing to accept the primordial traits of heroes even those not found in comic books. In other words, we also must be willing to "adapt" and appreciate the hero archetype and the invaluable lessons that heroes such as Gilgamesh, his brother Enkidu, Odysseus and Roland instill in each of us. They are without a doubt an extension of us. These characters, their stories and heroic acts teach us in the $21^{\text {st }}$ century that, even though our fascination with technology is certainly not a bad thing, we should not allow it to deter us from realizing something important: no matter how immune or indifferent certain people may feel to the dangers or hardships in life, they are also mortal just like these epic heroes and they need to express their human emotions as do Gilgamesh, Odysseus and Roland. In fact, through daily acts of kindness, understanding and compassion, no matter how great or small, we should all be inspired to bring out the heroic part in all of us. Only then, will the true hero inside each of us emerge and save our sense of humanity.

\section{Bibliography}

Bennett, Philip E. "Origins of the French Epic: The Song of Roland and Other French Epics." Approaches to Teaching the Song of Roland, Edited by Leslie Morgan and William W. Kibler, 57-65. New York: MLA, 2006.

Bertman, Stephen. Handbook to Life in Ancient Mesopotamia. New York: Oxford University Press, 2005.

Campbell, Joseph. The Hero with a Thousand Faces. Novaro: New World Library, 2008.

Campbell, Joseph. The Power of Myth, Edited by Betty Sue Flowers. New York: Doubleday, 1988.

Davis, Bryan M. The Archetypal Hero in Literature, Religion, Movies, and Popular Culture. Stephen F. Austin University, 11 Oct. 1997. Last modified December 21, 2013. http://tatsbox.com/hero/

Dante, Alighieri. The Divine Comedy: Inferno. Translated by John D. Sinclair. New York: Oxford University Press, 1939.

36. Robert S. McElvaine, "Heroes," Encyclopedia of the Great Depression vol. 1 (New York: Macmillan, 2004), 436. 
Fromm, Erich. Escape from Freedom. New York: Holt, Rinehart and Winston, 1976.

Gilgamesh. Translated by Stephen Mitchell. New York: Free Press, 2006.

Gordon, Walter K. Literature in Critical Perspectives. New York: Meredith Corporation, 1968.

Homer. The Iliad. Translated by Robert Fagles. New York: Penguin, 1991.

Homer. The Odyssey. Translated by Robert Fagles. New York: Penguin, 1997.

Jones, Catherine. "Roland versus Oliver." Approaches to Teaching the Song of Roland, Edited by Leslie Morgan and William W. Kibler. New York: MLA, 2006.

Jones, Colin. The Cambridge Illustrated History of France. New York: Cambridge University Press, 1994.

McElvaine, Robert S. "Heroes." Encyclopedia of the Great Depression vol. 1. New York: Macmillan, 2004.

Moore, Robert, and Douglas, Gillette. King, Warrior, Magician, Lover: Redefining the Archetypes of the Mature Masculine. San Francisco: Harper San Francisco, 1991.

Pertile, Lino. "Introduction to Inferno." The Cambridge Companion to Dante, Edited by Rachel Jacoff, 67-106. New York: Cambridge University Press, 2007.

Pindar. Odes for Victorious Athletes. Translated by Anne Pippin Burnett. Baltimore: The Johns Hopkins University Press, 2010.

Pomeroy, Sarah B., Burstein, Stanley M., Donlan, Walter, Roberts, Tolbert Jennifer, and Tandy, David. Ancient Greece: A Political, Social, and Cultural History. New York: Oxford University Press, 2012.

The Song of Roland. Translated by Frederick Goldin. New York: Norton, 1978. 
